Article

\title{
Probiotic and Antioxidant Potential of Lactobacillus reuteriLR12 and Lactobacillus lactisLL10 Isolated from Pineapple Puree and Quality Analysis of Pineapple-Flavored Goat Milk Yoghurt during Storage
}

\author{
Naif Abdullah Al-Dhabi ${ }^{1,+}$, Mariadhas Valan Arasu ${ }^{1,+}$, Ponnuswamy Vijayaraghavan ${ }^{2}$, \\ Galal Ali Esmail ${ }^{1}$ (D), Veeramuthu Duraipandiyan ${ }^{1}$, Young Ock Kim ${ }^{3}$, Hyungsuk Kim ${ }^{4}$ (D) and \\ Hak-Jae Kim $^{3, *}$ \\ 1 Department of Botany and Microbiology, College of Science, King Saud University, P.O. Box 2455, \\ Riyadh 11451, Saudi Arabia; naldhabi@ksu.edu.sa (N.A.A.-D.); mvalanarasu@ksu.edu.sa (M.V.A.); \\ gesmail@ksu.edu.sa (G.A.E.); avdpandiyan@gmail.com (V.D.) \\ 2 Bioprocess Engineering Division, Smykon Biotech Pvt Ltd, Nagercoil, Kanyakumari District, \\ Tamil Nadu 629 001, India; venzymes@gmail.com \\ 3 Department of Clinical Pharmacology, College of Medicine, Soonchunhyang University, Cheonan, \\ Chungcheongnam 31151, Korea; kyo9128abcd@gmail.com \\ 4 Department of Rehabilitation Medicine of Korean Medicine, College of Korean Medicine, \\ Kyung Hee University, Seoul 02447, Korea; kim0874@hanmail.net \\ * Correspondence: hak3962@sch.ac.kr; Tel./Fax: +82-1037872570 \\ + These authors equally contributed to this work.
}

Received: 7 September 2020; Accepted: 23 September 2020; Published: 23 September 2020

\begin{abstract}
In recent years, studies have focused on the therapeutic properties of probiotics to eliminate pathogenic microorganisms associated with various diseases. Lactobacilli are important probiotics groups that have been found to possess many health-promoting activities. This study was carried out to isolate LactobacillusreuteriLR12 and L. lactisLL10 from pineapple puree. The invitro analysis to evaluate probiotic characteristics of the isolated bacteria included survival in bile and acid tolerance. The cell-free supernatant of L. reuteri LR12 was effective against various pathogenic bacteria and fungi compared with L. lactisLL10. These two bacterial strains have strong anti-biofilm activity $(100 \%)$ against Enterococcus faecalis, Staphylococcus aureus, and Bacillus cereus. The bacterial strains exhibited adhesion properties to HT-29 cells (human colorectal adenocarcinoma). These bacteria showed DPPH- (2,2-diphenyl-1-picryl-hydrazyl-hydrate) free radical scavenging activity, scavenging of hydroxyl radical activity, superoxide radical scavenging activity, and reducing power activity in the range of $72 \% \pm 3 \%$ to $89.3 \% \pm 1.7 \%, 64 \% \pm 2.7 \%$ to $66.8 \% \pm 1.5 \%, 59.8 \% \pm 4.1 \%$ to $63.8 \% \pm 2.1 \%$, and $60.4 \% \pm 1.8 \%$ to $66.1 \% \pm 3.3 \%$, respectively. Pineapple puree was used as the starter culture with milk for 2 days for yogurt preparation. Pineapple puree increased flavor and showed the physicochemical properties of yogurt. The finding of the sensory evaluation revealed no significant change compared with the control, except the appearance of yogurt. These findings show that Lactobacilli and pineapple puree have potential use in various probiotic preparations for the fermentation industry.
\end{abstract}

Keywords: pineapple puree; lactic acid bacteria; yoghurt; post-fermentation; stable flavor 


\section{Introduction}

Intestinal microbial flora intertwines metabolic and signaling capabilities to provide various health benefits. In recent years, studies have focused on investigating appropriate therapeutic agentsfor their antibiotic potential and ability to eliminate multidrug-resistant (MDR) microorganisms [1]. Biofilm-producing Enterobacteriaceae and carbapenemase producing Klebsiellapneumoniaea are prevalent in gastrointestinal tract infections. MDR bacteria cause intestinal sepsis, which is a serious health condition. In spite of prophylactic measures and appropriate antibiotic administration to the individuals, increases in antibiotic exposure pose serious risks to antibiotic resistance. Most of the bacteria of Gram-negative type are resistant to ampicillin, cloxacillin, and gentamicin [2]. Gastrointestinal infections are very common among infants [3]. Superoxide anion radicals, hydrogen peroxide, and hydroxyl radicals have been reported as reactive oxygen species (ROS), but hydrogen peroxide is only one of the hyperactive oxygen free radicals. These byproducts are involved in a number of events. In the human body, free radicals are involved in oxidative stress [4]. Many factors, namely nitrogen oxides, herbicides, ozonization, radiation, and some metals, induce oxidative stress. In phagocytosis, bacteria are invaded, which stimulates the production of reactive oxygen species due the activity of NADPH oxidase, and this enzyme is also involved in phagocytes [5]. In living organisms, enzyme defenses and non-enzymatic antioxidant defenses are reported. Enzymes like glutathione reductase (GR), glutathione peroxidase (GPx), and superoxide dismutase (SOD) are involved in phagocytosis, whereas non-enzymatic substances like vitamin $\mathrm{E}$, vitamin $\mathrm{C}$, thioredoxin, and glutathione are involved in the antioxidant defense system [6]. Despite several known synthetic antioxidants, including butylatedhydroxyanisole and butylatedhydroxytoluene, involved in treating free radicals, investigating suitable, natural, and safer antioxidants from natural resources has received considerable attention [7]. In recent decades, several works have been carried out on the probiotic potential of microorganisms, because these microorganisms have numerous health benefits, including antimicrobial and antioxidant activities [8-10]. Probiotics are living microbial food supplements and produce various beneficial biomolecules, including bacteriocins [11]. Probiotics add critical value to certain functional foods. Lactobacilli are important probiotics strains found to possess many health-promoting activities, as well as a long, safe history of being consumed by human beings [12]. For example, Lactobacillus acidophilus ATCC 4356 shows strong antioxidant activity and the capability of inhibiting linoleic acid. These strains survive and colonize the gastrointestinal tract of the host organism. The survival ability of probiotic organisms in the gastrointestinal tract is mainly influenced by the buffering capacity of the supplemented food. Yogurt, cheese, and skimmed milk are formulated with $\mathrm{pH}$ ranging from 3.5 to 4.5 and high buffering capacity, which increase the $\mathrm{pH}$ of the gastrointestinal tract and thus enhance the stability of probiotic strains [13]. In recent years, research has focused on the isolation of new bacterial strains with beneficial effects that mainly constitute natural inhabitants in the gastrointestinal tract. For example, the beneficial effect of Akkermansiamuniciphila with respect to gut modulation and immune modulation has been analyzed [14]. The selected bacterial strains must survive food processing and food storage conditions and withstand various stress conditions encountered in the upper gastrointestinal tract of the host organism. Hence, the suitable selection of probiotic bacteria and their potential delivery remains a challenge, with the main focus on sustaining the viability of the probiotic bacteria in the final formulated food product. Food and food products are widely used for the isolation of Lactobacilli. The pineapple fruit is an edible fruit made of flesh, with simple sugars like fructose and sucrose. This fruit is rich in antioxidants (vitamin C), and consumption of this fruit is beneficial against various organisms and scavenging activity [15]. Fermentation of pineapple puree and the survival of probiotic bacteria in pineapple juice are not very clear. In this study, two Lactobacillus sp. were isolated from pineapple puree, and biological activities were studied. Then, pineapple puree was used as the starter culture for goat milk yogurt production for nutraceutical applications. 


\section{Materials and Methods}

\subsection{Pineapple Puree Preparation}

A freshly collected pineapple was used for the preparation of pineapple puree. About $500 \mathrm{~g}$ of pineapple pulp was prepared by using $50 \mathrm{~g}$ fruit body ground with double-distilled water and was autoclaved. It was transferred into an Erlenmeyer flask containing $200 \mathrm{~mL}$ of raw milk. In this mix, gelatin $(2 \%, w / v)$, sugar $(2 \%, w / v)$, and salt $(0.8 \%, v / w)$ were incorporated and stirred continuously. The mixture was then dispensed into a sterile container and kept at $37^{\circ} \mathrm{C}$ for $72 \mathrm{~h}$. The stability of the sample was analyzed continuously and was used for the isolation of Lactobacilli.

\subsection{Isolation, Screening, and Characterization of Lactobacillus Strains}

About $0.1 \mathrm{~mL}$ of pineapple puree sample was placed on MRS (Man, Rogosa, Sharpe) agar containing $\mathrm{CaCO}_{3}$ (Himedia, Mumbai, India) and further incubated at $30 \pm 2{ }^{\circ} \mathrm{C}$ for $72 \mathrm{~h}$ under anaerobic state. The bacterial isolates were selected based on acid production (clear zone around the colony) on MRS medium containing $\mathrm{CaCO}_{3}$ [16]. Acid-producing organisms were sub-cultured prior to use in MRS liquid medium followed by incubation at $37^{\circ} \mathrm{C}$ for $72 \mathrm{~h}$. The growth of the bacterial strains was measured at $600 \mathrm{~nm}$ using a UV-visible spectrophotometer. The bacterial strains (LR12 and LL10), which showed maximum cell density (1.090 \pm 0.1 and $1.048 \pm 0.1$ OD [optical density]) at $600 \mathrm{~nm}$, were subjected to morphological, biochemical, and $16 S \mathrm{rDNA}$ sequencing.

\subsection{LAB Strain and Resistance}

The antibiotic resistance pattern of Lactobacillus (LAB) strains (LR12 and LL10) was evaluated using the disc diffusion method. In this method, about $100 \mu \mathrm{L}$ of Lactobacillus strains (LR12 and LL10) were placed on MRS agar medium, and then the commercial antibiotic discs were placed. The culture plates were incubated for $24 \mathrm{~h}$ at $30 \pm 2{ }^{\circ} \mathrm{C}$, and antibiotic resistance was determined [17].

\subsection{Probiotic Characterization of $L A B$}

To analyze the acid tolerance of LAB strains (LR12 and LL10), MRS medium was preparedwith3\% bile salts. Then, $100 \mu \mathrm{L}$ of MRS broth (log phase) was inoculated and incubated at $37^{\circ} \mathrm{C}$ for $24 \mathrm{~h}$, and its tolerance level was evaluated. To evaluate acid tolerance, $3 \%$ oxgall acid was added to the MRS broth medium and inoculated at the log phase of the bacterial strain. The culture was incubated at $37^{\circ} \mathrm{C}$ for $24 \mathrm{~h}$, and the oxgallic acid tolerance (\%) was evaluated. The viability of bacteria was calculated after serial dilution and growth on MRS agar medium. Acid and bile tolerance experiments were repeated three times, and an average value was considered for analysis [16]. The survival rate was determined using the given formula:

$$
\text { Survival rate }(\%)=(\text { cell no. after reaction }(\mathrm{CFU}) / \text { initial cell no. }(\mathrm{CFU})) \times 100
$$

\subsection{LAB Strains and Adhesion Properties}

To evaluate the adhesion properties of Lactobacillus strains (LR12 and LL10) on HT-29 cells (intestinal epithelial cells), cells were added to a 24-well microtiter plate at $2 \times 10^{5}$ cell concentration and incubated for $24 \mathrm{~h}$ at $37 \pm 2{ }^{\circ} \mathrm{C}$. On the developed HT-29 monolayer, Lactobacillus strains (LR12 and LL10) were seeded at $1 \times 10^{8} \mathrm{CFU} /$ well. The microtiter plate was incubated for about $2 \mathrm{~h}$ at $37 \pm 2{ }^{\circ} \mathrm{C}$ with $5 \% \mathrm{CO}_{2}$ using a $\mathrm{CO}_{2}$ incubator. Further, the non-adherent HT-29 cells were removed using PBS (Phosphate Buffer Saline) by repeat washing. Then, $0.1 \%$ Triton X-100 was used on each well, and bacterial cells were harvested. The cells were then serially diluted and spread on MRS agar plates [18]. The plates were incubated for $24 \mathrm{~h}$ at $37^{\circ} \mathrm{C}$, and adhesion properties were calculated as below:

Adhesion ability $(\%)=($ adhered cell no. $(\mathrm{CFU}) /$ initial cell no. $(\mathrm{CFU})) \times 100$ 


\subsection{Test Organisms for Antimicrobial Assay}

Escherichia coli (ATCC 8739), Pseudomonas aeruginosa (ATCC 15442), Salmonella typhi (ATCC 13311), Bacillus cereus (ATCC 14579), Enterococcus faecalis (ATCC 29212), and Staphylococcus aureus (ATCC 6538) bacteria were used for analysis. Aspergillus niger (ATCC 16404), A. flavus (ATCC 9643), A. nidulans (ATCC 38163), and Penicillium expansum (ATCC 7861) fungal species were also tested. Bacterial strains were cultured in nutrient broth medium (Himedia, Mumbai, India) for $18 \mathrm{~h}$ at $37^{\circ} \mathrm{C}$. The fungal strains were cultured in potato dextrose broth for $72 \mathrm{~h}$ at $37^{\circ} \mathrm{C}$. The growth of culture was observed using a UV-visible spectrophotometer at $600 \mathrm{~nm}$.

\subsection{Preparation of Cell Free Supernatant}

The Lactobacilli strains (LR12 and LL10) were cultured individually in MRS broth (Himedia, Mumbai, India) medium for $24 \mathrm{~h}$ at $37^{\circ} \mathrm{C}$. The culture was centrifuged at $10,000 \mathrm{rpm}$ for $20 \mathrm{~min}$ at $4{ }^{\circ} \mathrm{C}$. The supernatant was filter sterilized using a $0.22 \mu \mathrm{m}$ filter, as described earlier [19].

\subsection{Antibacterial Susceptibility Testing of LAB}

To determine antagonistic activity, the disc diffusion method was followed. The discs were prepared with Whatman's filter paper (no. 1) with a diameter of $6 \mathrm{~mm}$. The paper was sterilized, and the prepared disc was aseptically soaked into the cell-free supernatant of LAB. Sterile Mueller-Hinton agar (MHA) was aseptically poured into sterile Petri dishes, and the overnight culture of test organisms was inoculated. Then, sterile forceps were used to place the disc aseptically on the surface of MHA plates. Ciprofloxacin was used as a positive control, and the plates were incubated for $24 \mathrm{~h}$ at $37^{\circ} \mathrm{C}$. To study the influence of organic acid of the cell-free extract on antimicrobial activity, the $\mathrm{pH}$ of the filter sterilized supernatant was adjusted to 6.5 by using $1 \mathrm{~N} \mathrm{NaOH}$ [20]. The plates were observed for zones of inhibition (mm).

\subsection{Antifungal Activity of Lactobacillus Strains}

Antifungal activity was evaluated using the agar diffusion method, as suggested by Arasu et al. [21]. LAB strains were streaked on the plates containing $25 \mathrm{~mL}$ MRS agar, and the plates were incubated for three days at $37^{\circ} \mathrm{C}$. About $50 \mu \mathrm{L}$ of fungal suspension with $10^{8} \mathrm{CFU} / \mathrm{mL}$ was incorporated into the PDA medium. It was overlaid on MRS agar solid medium with the Lactobacillus strains LR12 and LL10. The culture plates were incubated for three days at $37^{\circ} \mathrm{C}$, and the zone of inhibition was analyzed.

\subsection{Minimum Inhibitory Concentration}

Minimum inhibitory concentrations (MICs) of both bacteria and fungi were evaluated separately by the tube dilution method. To determine the MIC of bacteria and fungi, one milliliter of cell-free extract of $\mathrm{LAB}$ was serially diluted up to a predetermined concentration. All tubes were inoculated with fungi $\left(10^{8} \mathrm{CFU} / \mathrm{mL}\right)$ and bacteria separately. The antifungal agent ketoconazole was used as standard. The MIC was analyzed as the lowest quantity of the cell-free extract that completely inhibited the growth of the organisms.

\subsection{Determination of Minimum Bactericidal Concentration}

To evaluate the minimum bactericidal concentration (MBC), tubes without any sign of turbidity/ growth in MIC samples were cultured on nutrient agar medium and incubated for $24 \mathrm{~h}$ at $37 \pm 2{ }^{\circ} \mathrm{C}$. The lowest concentration of cell-free extract of LAB that effectively inhibited growth was calculated as the $\mathrm{MBC}$.

\subsection{2. $\beta$-Glucuronidase Assay}

The selected bacterial strains (LR12 and LL10) were cultured in MRS liquid medium at $37^{\circ} \mathrm{C}$. After $18 \mathrm{~h}$ of incubation, the bacterial cells were centrifuged at $5000 \times \mathrm{g}$ for $10 \mathrm{~min}$, washed three 
times with PBS, and mixed with lysis buffer (acetone/toluene, 9:1 $v / v$ ). Then, an $80 \mu \mathrm{L}$ aqueous layer was separated and mixed with $\rho$-nitrophenyl- $\beta$-D-glucuronide $(5 \mathrm{mM})$ and kept for $37^{\circ} \mathrm{C}$ at $30 \mathrm{~min}$. The enzymatic reaction was stopped by adding $0.5 \mathrm{M} \mathrm{Na}_{2} \mathrm{CO}_{3}$, and the released $\mathrm{pNP}$ was evaluated using a microtiter plate reader at $405 \mathrm{~nm}$ [22].

\subsection{Biofilm Inhibition Assay}

A biofilm inhibition assay was performed using biofilm forming E. coli, P. aeruginosa, S. typhi, B. cereus, and E. faecalis, as described by Wu et al. [23]. These bacterial strains were prepared at $1 \times 10^{6} \mathrm{CFU} / \mathrm{mL}$ concentration and inoculated in brain-heart infusion (BHI) broth (Himedia, Mumbai, India), and culture extracts of the Lactobacillus strains (LR12 and LL10)were separately added at $35 \mathrm{mg} / \mathrm{mL}$ concentrations. The microtiter plate was incubated for about $18 \mathrm{~h}$ and, the non-adherent cells were removed using sterile double-distilled water. Then the adherent bacterial cells were fixed by using $250 \mu \mathrm{L}$ methanol for $10 \mathrm{~min}$, and the plates were air-dried. The fixed biofilms were stained by using crystal violet $(0.2 \%, 300 \mu \mathrm{L})$ prepared in double-distilled water. The crystal violet stain of adherent cells was extracted using glacial acetic acid $(33 \%, 200 \mu \mathrm{L})$. The absorbance of the sample was read at $540 \mathrm{~nm}$, and biofilm inhibition efficiency was analyzed.

$$
\text { Biofilm inhibition rate }(\%)=(1-(\text { absorbance of sample }) /(\text { absorbance of control })) \times 100
$$

\subsection{Inhibition of Glucan Synthesis}

The bacterial test strain was inoculated in BHI broth and incubated for $24 \mathrm{~h}$ at $37^{\circ} \mathrm{C}$. It was further centrifuged (at $5000 \times \mathrm{g}$ ), and the aliquots were kept for $15 \mathrm{~min}$ at $4{ }^{\circ} \mathrm{C}$. The sample was filtered using a membrane filtration unit $(0.2 \mu \mathrm{m}$ membrane filter). Then $20 \mu \mathrm{L}$ of crude sample was transferred in a reaction mixture containing $180 \mu \mathrm{L}$ of LAB supernatant and potassium phosphate buffer ( $62.5 \mathrm{mM}, \mathrm{pH}$ 6.5) containing $0.25 \mathrm{~g}$ of sodium azide and $12.5 \mathrm{~g}$ of sucrose, and incubated for $30 \mathrm{~h}$ at $37^{\circ} \mathrm{C}$. The adhered sample with tubes were collected and sonicated for complete dispersion. Finally, the amount of water-insoluble glucan was calculated by measuring the sample at $550 \mathrm{~nm}$ [24], and the glucosyltransferase (GTF) inhibition rate was determined as described below:

GTF inhibition rate $(\%)=(1-($ absorbance of treated sample $) /($ absorbance of control $)) \times 100$

\subsection{In Vitro Antioxidant Activity of LAB Strains}

\subsubsection{DPPH Free Radical Activity}

Briefly, 12.5, 25, 50, and $100 \mu \mathrm{L}$ extracts of Lactobacillus isolates (LR12 and LL10) were added into DPPH radical solution $(0.05 \mathrm{mM})$. The solutions were mixed and kept in the dark for $30 \mathrm{~min}$ [25]. The absorbance samples were measured at $517 \mathrm{~nm}$. The scavenging ability was calculated as below:

$$
\text { Scavenging ability } \left.(\%)=\left(1-A_{\text {sample }}-A_{\text {blank }}\right) / A_{\text {control }}\right) \times 100
$$

\subsubsection{Scavenging of Hydroxyl Radicals}

Scavenging activity of hydroxyl radicals by bacteria was measured according to the method of Guo [13]. Overnight, bacterial samples with different concentrations $(12.5,25,50$, and $100 \mu \mathrm{L})$ were inoculated into samples containing O-phenanthroline $(0.1 \%, w / v), 2.5 \mathrm{mM} \mathrm{FeSO}_{4}$, and $20 \mathrm{mM} \mathrm{H}_{2} \mathrm{O}_{2}$. The samples were then incubated for $90 \mathrm{~min}$ at $37^{\circ} \mathrm{C}$. The absorbance samples were read at $536 \mathrm{~nm}$, and free radical scavenging activity was determined as follows:

$$
\text { Scavenging activity }(\%)=\left[\left(A_{1}-A_{2}\right) /\left(A_{1}-A_{0}\right)\right] \times 100 \%
$$




\subsubsection{Superoxide Radical Scavenging Activity}

Samples were mixed at various concentrations $(12.5,25,50$, and $100 \mu \mathrm{L})$ with pyrogallic acid $(0.05 \mathrm{M}, 0.1 \mathrm{~mL})$. The samples were incubated at $25^{\circ} \mathrm{C}$ for $30 \mathrm{~min}$ in the dark. Absorbance samples was measured at $320 \mathrm{~nm}$, and superoxide radical scavenging was analyzed [26] as follows:

$$
\text { Scavenging rate }(\%)=\left[1-A_{320 \text { nm sample }}-A_{320 \text { nm blank }}\right] \times 100 \%
$$

\subsubsection{Reducing Power Assay}

Samples at various concentrations $(12.5,25,50$, and $100 \mu \mathrm{L})$ were mixed with $1 \%$ potassium ferricyanide solution. The reaction mixture was incubated for $20 \mathrm{~min}$ at $50{ }^{\circ} \mathrm{C}$. The mixture was cooled, and $10 \%$ trichloroacetic acid was added. The mixture was centrifuged, the upper layer was gently mixed with ferric chloride solution $(0.1 \%)$, and the absorbance of the sample was analyzed at $700 \mathrm{~nm}$ [27].

\subsection{Yogurt Preparation}

\subsubsection{Yogurt Preparation Using Pineapple Puree}

Goat milk was freshly collected and used for the preparation of yogurt. Yogurt preparation was based on the method suggested by Lee and Lucey [28], with few modifications. The collected milk was heated at $90 \pm 2{ }^{\circ} \mathrm{C}$ for $5 \mathrm{~min}$, and $5.0 \%(w / v)$ table sugar was added. The milk was then rapidly cooled to between 40 and $42{ }^{\circ} \mathrm{C}$. Then, the starter culture (pineapple puree) was added at $1.0 \%, 2.0 \%$, and $3.0 \%$ levels and incubated for two days for the process of forming yogurt. After $48 \mathrm{~h}$ of treatment, yoghurt was analyzed for various physicochemical factors and microbiological analyses.

\subsubsection{Analysis of Physicochemical Parameters of Yogurt}

The fat, ash content, acidity, $\mathrm{pH}$, and dry matter of the yogurt were determined using the standard method [29]. Titratable acidic level and $\mathrm{pH}$ of the sample were determined after 2 days of yogurt preparation. The sugar content of yogurt was determined and expressed as $\%$ sucrose. The solid non-fat was also measured using the following formula:

$$
\text { Solid non-fat }(\%)=\% \text { dry matter }-\% \text { fat content }
$$

\subsubsection{Analysis of Microorganisms and Sensory Evaluation of Yogurt}

One gram of the yogurt sample was transferred into $99 \mathrm{~mL}$ sterile, double-distilled water, and samples were prepared at various dilutions $\left(10^{-1}\right.$ to $\left.10^{-7}\right)$. Total plate count agar was used for the determination of total bacteria population in the sample, whereas potato dextrose agar was used for the determination of total fungi. An appropriately diluted sample was spread on MacConkey Agar medium for the determination of total coliforms. All plates were incubated at $37^{\circ} \mathrm{C}$ for $24 \mathrm{~h}$ for bacteria and $72 \mathrm{~h}$ for fungi. A colony counter was used for the determination of developed bacterial and fungal colonies. Twenty people were selected to evaluate the taste and flavor of pineapple yogurt. About $20 \mathrm{~mL}$ of product was served to all participants, and the results were registered. Clear instructions were given to the participants to clean their palates. Sensory scales were given to the participants to give ratings ranging from 0 to 10, with 0 being the lowest and 10 being the highest score in terms of taste. Sensory characteristics, such as appearance, texture, and flavor were improved in the puree-fermented yogurt [30].

\subsection{Statistical Analysis}

One-way analysis of variance was used to test the significance of variation in all experiments. A $p$-value of $<0.05$ was considered as statistically significant. 


\section{Results and Discussion}

\subsection{Isolation of Probiotic Lactobacillus Strains}

Most probiotic products have been used as functional food. In this study, two probiotic organisms were isolated from pineapple for the preparation of functional food, because the presence of high sucrose and fructose is preferred for the growth of Lactobacillus sp. Two probiotic isolates, L. reuteri LR12 and L. lactisLL10, exhibited weak resistance towards the antibiotics ampicillin, tetracycline, chloramphenicol, and doxycycline, while showing strong resistance against gentamycin, kanamycin, streptomycin, and ciprofloxacin. The findings of antibiotic susceptibility are highly similar to previous reports that have also shown the absence of strong resistance against various antibiotics from natural fermented sources [31]. Recently, probiotic bacterial strains from the genus Enterococcus were isolated from an Argentinean cheese, and their application as a starter culture for the production of cheese was suggested [32]. Probiotic bacteria were isolated from unfermented and fermented products of animal origin, such as honey, fish, seafood, and raw cured cold meats [33]. Recently, the probiotic properties of bacteria, such as Lactobacillus fermentum R6, Lactobacillus curvatus R5, Lactobacillus brevis R4, and Pediococcuspentosaceus R1 have been characterized [34].

\subsection{Probiotic Properties of the LAB Strains}

The tolerance effects of both Lactobacillus species were compared. When the bacteria were grown under 3\% bile and 3\% oxgall acid conditions, the survival power of L. reuteriLR12 was $85.3 \%$, and the $\log$ CFU/mL value was $9.12 \pm 0.07$. The survival rate of $L$. reuteriLR12 was improved (100\%) in the presence of bile salts. In L. lactisLL10, the initial $\log$ CFU was $8.65 \pm 0.31 / \mathrm{mL}$, and this value increased to $9.07 \pm 0.77 \log \mathrm{CFU} / \mathrm{mL}$ (Table 1 ). Cell count was also increased in the presence of bile salts $(9.29 \pm 0.15 \mathrm{CFU} / \mathrm{mL})$. Bile-salt hydrolases (BSHs) showed adaption to the organism to survive in a bile-containing environment [35]. BSHs are inducible enzymes in Lactobacillus, and in L. plantarum expression of the bsh gene enhanced enzyme production over six-fold after exposure of this organism to $2 \%$ bile. BSH activities varied based on the source of the sample and host species. Increased levels of BSHs in a human host are related to a higher cholesterol-removing ability [36]. The finding suggested that enzymes of Lactobacillus sp. play an important role for gut bacterial flora, mainly contributing to the ability of bile tolerance.

Table 1. Probiotic characteristics of Lactobacillus (LAB) isolated from pineapple fruit.

\begin{tabular}{ccc}
\hline Characteristics & L. reuteri & L. lactis \\
\hline Cell count at initial stage $(\log$ CFU/mL) & $9.27 \pm 0.38$ & $8.65 \pm 0.31$ \\
Cell count at gastric conditions $(\log$ CFU/mL) & $9.12 \pm 0.07$ & $9.07 \pm 0.77$ \\
Cell count in bile salts $(\log$ CFU/mL) & $9.32 \pm 0.05$ & $9.29 \pm 0.15$ \\
$\beta$-glucuronidase activity $(\mathrm{U} / \mathrm{mL})$ & Not detected & Not detected \\
Adhesion ability $(\%)$ & $71 \pm 1.08$ & $76.3 \pm 1.93$ \\
\hline
\end{tabular}

Data expressed as mean \pm standard deviation.

\section{3. $\beta$-Glucuronidase Assay and Adhesion Ability}

$\beta$-glucuronidase activity was analyzed, and it was found that the selected Lactobacillus strains (LR12 and LL10) did not produce this enzyme. $\beta$-glucuronidase activity is one of the important probiotic characteristics. In Lactobacillus species, $\beta$-glucuronidases liberate mutagens and toxins that are generally excreted with the bile juice. This process leads to elevated levels of carcinogenic compounds, thus enhancing the risk of cancer in the gut, as has been reported by Gill and Rowland [37]. In cancer patients, increased $\beta$-glucuronidase levels have been reported compared with normal individuals [38]. L. reuteriLR12 has a stronger adhesion ability $(76.3 \pm 1.93 \%)$ than L. lactisLL10 (71 $\pm 1.08 \%)($ Table 1$)$. Adhesion properties are an important characteristic of probiotics. Kos et al. [39] reported a correlation between hydrophobicity and adhesion ability in Lactobacillus strains. Colonization and adherence 
of Lactobacillus in the gut is a prerequisite for the isolates to exhibit various beneficial effects on humans [40]. Analysis of adhesions to the HT-29 intestinal epithelial cell line of Lactobacillus isolates has been considered as an effective in vitro method for screening isolates for probiotic potential [41]. Tuo et al. [42] reported adhesion properties and auto aggregation among various bacterial species, and positive correlations were observed between adhesion and auto aggregation.

\subsection{Antimicrobial Activity of Lactobacillus Strains against Microbial Pathogens}

The cell-free extract of the tested Lactobacillus strains (LR12 and LL10) showed potent antimicrobial activity. The zone of inhibition varied widely. Lactobacillus LR12 showed high potential activity against $S$. aureus $(27 \pm 1$ and $26 \pm 2 \mathrm{~mm}$ ) and E. coli $(28 \pm 2$ and $25 \pm 1 \mathrm{~mm}$ ) (Table 2). The selected Lactobacillus strains (LR12 and LL10) were analyzed to determine MIC against microbial pathogens, and the results are shown in Table 3. The cell free extract of L. reuteri (LR12) showed a very low MIC value against P. aeruginosa $(6.25 \mu \mathrm{g} / \mathrm{mL})$, E. fecalis $(6.25 \mu \mathrm{g} / \mathrm{mL})$ and P. expansum $(6.25 \mu \mathrm{g} / \mathrm{mL})$. The extract of L. lactisLL10 showed the lowest MIC value against P. aeruginosa $(6.25 \mu \mathrm{g} / \mathrm{mL})$ and B. cereus $(6.25 \mu \mathrm{g} / \mathrm{mL})$. The activities against bacterial pathogens were mainly due to the production of hydrogen peroxide, non-lactic acid molecules, and bacteriocin-like molecules [43]. Bacteriocins are enzymatic, degradable, proteinaceous compounds, and bacteriocins such as pediocin, nisin, and sakacin show potent antibacterial activity against bacterial pathogens [44]. The selected Lactobacillus sp. (LR12 and LL10) showed higher antifungal activities against Penicillium sp. than other fungal strains. This result is comparable with previous findings [21]. The antibacterial activity of Lactobacillus has been reported previously; for example, the reported Lactobacillus strains showed antibacterial activity against C. difficile [45], E. coli [46], Shigella spp. [47], P. aeruginosa [48], and S. aureus [49]. Recently, Wang et al. [50] isolated L. plantarum from Tibetan yaks and reported an inhibitory effect against Staphylococcus aureus and E. coli. The antibacterial activity of Lactobacillus paracasei subsp. paracasei was reported against Staphylococcus aureus involved in colonic and intestinal injury [51]. In this study, the sample showed high activity against $S$. aureus, and the neutralized cell-free extract did not show any antimicrobial properties. This revealed that the low $\mathrm{pH}$ value of cell-free extract due to the presence of organic acids, especially lactic acid produced by the selected Lactobacilli strains, is highly responsible for antimicrobial potential. Zhang et al. [52] also previously reported a loss of antimicrobial activity in the cell-free extract after neutralization.

Table 2. Antimicrobial activity of Lactobacillus strains against bacteria and fungi.

\begin{tabular}{ccc}
\hline \multirow{2}{*}{ Bacterial Strain } & \multicolumn{2}{c}{ Zone of Inhibition $(\mathbf{m m})$} \\
\cline { 2 - 3 } & L. reuteri & L. lactis \\
\hline E. coli & $28 \pm 2$ & $25 \pm 0$ \\
S. typhi & $24 \pm 1$ & $23 \pm 2$ \\
P. aeruginosa & $26 \pm 2$ & $23 \pm 1$ \\
B. cereus & $24 \pm 3$ & $22 \pm 1$ \\
S. aureus & $27 \pm 1$ & $26 \pm 2$ \\
A. niger & $13 \pm 1$ & $21 \pm 2$ \\
A. flavus & $15 \pm 0$ & $16 \pm 0$ \\
A. nidulans & $10 \pm 0$ & $\mathrm{ND}$ \\
P. expansum & $\mathrm{ND}$ & $\mathrm{ND}$ \\
\hline
\end{tabular}

ND: No results detected. 
Table 3. Minimum inhibitory concentrations of the LAB cell-free supernatant against tested microbial strains.

\begin{tabular}{ccc}
\hline \multirow{2}{*}{ Microorganisms } & Minimum Inhibitory Concentration $(\mathbf{M I C})(\boldsymbol{\mu g} / \mathbf{m L})$ \\
\cline { 2 - 3 } & L. reuteri & L. lactis \\
\hline P. aeruginosa & 6.25 & 6.25 \\
E. coli & 25.00 & 12.50 \\
S. typhi & 12.50 & 25.00 \\
S. aureus & 6.25 & 25.00 \\
E. faecalis & 12.50 & 12.50 \\
B. cereus & 12.50 & 6.25 \\
A. niger & $>25.00$ & 12.50 \\
A. flavus & $>25.00$ & 25.00 \\
A. nidulans & 12.50 & 25.00 \\
P. expansum & 6.25 & 12.50 \\
\hline
\end{tabular}

\subsection{Inhibition of Biofilm and Glucan Formation}

The bacterial strains (LR12 and LL10) showed inhibitory properties against biofilm-forming bacterial pathogens. L reuteriLR12 showed s $53 \% \pm 1.3 \%$ biofilm inhibition rate against $E$. coli and $68 \% \pm 3.2 \%$ against P. aeruginosa, whereas L. reuteri LR12 and L. lactis LL10 showed $68 \% \pm 3.2 \%$ and $54 \% \pm 1.5 \%$ activity against $P$. aeruginosa. These two LAB strains have strong biofilm activity $(100 \%)$ against $S$. aureus, E. faecalis, and B. cereus (Table 4). The biofilm inhibition property of Lactobacillus has been previously reported by Melo et al. [53]. Some bacterial species have the ability to produce various substances with anti-adhesive properties. For example, Lactobacillus fermentum produced biosurfactant-like substances and inhibited biofilm formation of S. mutans [54]. In a study, a lipopeptide extracted from Bacillus subtilis showed anti-adhesive properties against Staphylococcus aureus [55]. According to the ionic characteristics of the hydrophilic region, the amphipathic molecules are classified as anionic, cationic, zwitterionic, and non-ionic substances. Among these, cationic amphiphilic molecules have the potential to inhibit bacterial biofilm. These amphiphilic molecules effectively prevent the aggregation of bacterial cells [56]. The present findings revealed the inhibitory effect of the biosynthesis of glucan from S. aureus. L. reuteriLR12 extract had an inhibition rate of $49.2 \% \pm 1.7 \%$ and $33.5 \% \pm 3.1 \%$ against $S$. aureus and E. coli, respectively. L. lactisLL10 extract showed the maximum inhibitory effect $(40.2 \% \pm 2.9 \%)$ against $S$. aureus (Table 5$)$.

Table 4. Biofilm inhibitory properties of Lactobacillus strains against bacterial strains.

\begin{tabular}{ccc}
\hline \multirow{2}{*}{ Bacteria } & \multicolumn{2}{c}{ Biofilm Inhibition Rate (\%) } \\
\cline { 2 - 3 } & L. reuteri & L. lactis \\
\hline P. aeruginosa & $68 \pm 3.2$ & $54 \pm 1.5$ \\
E. coli & $53 \pm 1.3$ & $73 \pm 3.6$ \\
E. faecalis & $100 \pm 0$ & $100 \pm 0$ \\
S. aureus & $100 \pm 0$ & $100 \pm 0$ \\
B. cereus & $100 \pm 0$ & $100 \pm 0$ \\
\hline
\end{tabular}

Table 5. Inhibitory property of LAB on glucan.

\begin{tabular}{ccc}
\hline \multirow{2}{*}{ Bacteria } & \multicolumn{2}{c}{ Inhibition (\%) } \\
\cline { 2 - 3 } & L. reuteri & L. lactis \\
\hline P. aeruginosa & $28.2 \pm 2.4$ & $37.2 \pm 2.6$ \\
E. coli & $33.5 \pm 3.1$ & $18.3 \pm 3.8$ \\
S. aureus & $49.2 \pm 1.7$ & $40.2 \pm 2.9$ \\
B. cereus & $21.8 \pm 2.4$ & $20.4 \pm 1.5$ \\
\hline
\end{tabular}




\subsection{Antioxidant Activity of $L A B$}

The selected Lactobacillus strains showed DPPH, hydroxyl radical, superoxide, and reducing power activities, and the results are described in Tables 6 and 7. At $100 \mu \mathrm{L}$ concentration, the sample from $L$. reuteri showed $89 \% \pm 21 \%$ DPPH activity, $80 \% \pm 3.2 \%$ hydroxyl radical antioxidant scavenging activity, $89 \pm 3 \%$ superoxide radical antioxidant scavenging activity, and $90 \% \pm 6.8 \%$ reducing activity. In L. lactisLL10, increased hydroxyl radical antioxidant activity was obtained for L. reuteri. In living organisms, an elevated level of oxygen radical byproducts can be obtained during the mitochondrial electron transport of aerobic respiration [57]. Many Lactobacillus strains show hydrogen peroxide antioxidant activity. Exopolysaccharides of L. lactis have exhibited promising antioxidant activity [58]. Certain Lactobacillus species have also degraded superoxide anions and hydrogen peroxidase [59]. The probiotic strains Lactobacillus fermentum E18 and Lactobacillus fermentum E3 have shown antioxidant properties [60]. A crude sample extracted from LAB strains showed antioxidant activities because of the presence of non-enzymatic substances and intracellular antioxidant enzymes [61]. In LAB, antioxidant enzymes, such as NADH oxidase, glutathione reductase, glutathione S-transferase, catalase, glutathione peroxidase, and feruloyl esterase, counteract oxidative stress $[62,63]$. The intracellular enzymes extracted from the bacterial cells by cell disruption showed antioxidant properties.

Table 6. Antioxidant activity of cell-free extract isolated from L. reuteriLR12.

\begin{tabular}{ccccc}
\hline Sample $(\boldsymbol{\mu g} / \mathbf{m L})$ & DPPH Scavenging & Hydroxyl Radical & Superoxide Radical & Reducing Power \\
\hline 12.5 & $28 \pm 1.3$ & $33 \pm 2.3$ & $6.2 \pm 0.56$ & $14.2 \pm 1.5$ \\
25 & $33 \pm 2.9$ & $43 \pm 2.4$ & $38.4 \pm 1.5$ & $30.5 \pm 1.1$ \\
50 & $53 \pm 3.8$ & $51 \pm 3.2$ & $52.3 \pm 4.3$ & $56.4 \pm 3.2$ \\
75 & $87 \pm 2.7$ & $76 \pm 1.9$ & $79.6 \pm 3.9$ & $80.2 \pm 2.8$ \\
100 & $89 \pm 2.1$ & $80 \pm 2.2$ & $89.2 \pm 2.1$ & $90.4 \pm 1.7$ \\
\hline
\end{tabular}

Table 7. Antioxidant activity of cell free extract isolated from L. lactisLL10.

\begin{tabular}{ccccc}
\hline Sample $(\mu \mathrm{g} / \mathrm{mL})$ & DPPH Scavenging & Hydroxyl Radical & Superoxide Radical & Reducing Power \\
\hline 12.5 & $15 \pm 1.5$ & $20 \pm 3.9$ & $28 \pm 3.4$ & $12.4 \pm 3.2$ \\
25 & $69 \pm 2.1$ & $44 \pm 2.8$ & $31 \pm 2.5$ & $20.4 \pm 1.9$ \\
50 & $78 \pm 5.3$ & $53 \pm 1.6$ & $48 \pm 3.3$ & $49.2 \pm 2.3$ \\
75 & $81 \pm 1.5$ & $89 \pm 2.7$ & $78 \pm 2.1$ & $75.3 \pm 3.4$ \\
100 & $90 \pm 3.7$ & $90 \pm 3.3$ & $84 \pm 1.6$ & $86.5 \pm 1.7$ \\
\hline
\end{tabular}

\subsection{Changes inpH Value of Yogurt during Storage}

The $\mathrm{pH}$ of the yogurt was analyzed for a period of 28 days, and a decrease of $\mathrm{pH}$ value was observed at $3 \%$ puree. However, this decreased level was not significant at $1 \%$ and $2 \%$ puree-inoculated yogurt $(p>0.05)$. Yoghurt with $3 \%$ puree-inoculated medium had a significantly reduced $\mathrm{pH}$. The continuous decrease of $\mathrm{pH}$ value of the yoghurt indicated the activity of lactic acid bacteria at lower temperatures. However, the $\mathrm{pH}$ of the yoghurt changed based on the nutrient content and availability. The $\mathrm{pH}$ changes did not affect the quality and physical properties of yoghurt. The variations of $\mathrm{pH}$ value of yogurt for four weeks are shown in Figure 1. Nikoofar et al. [64] analyzed the pH value of yogurt prepared with quince seed mucilage. The $\mathrm{pH}$ value of the yoghurt decreased continuously during storage. The $\mathrm{pH}$ value decreased very little up to day 9, but a sudden decrease was observed at day 10 . In the present study, the $\mathrm{pH}$ changes were similar to those observed in yogurts containing inulin [65] and waxy maize [66]. Thus, using pineapple puree in yogurt production had no significant negative impact on the bioprocess. In this study, the $\mathrm{pH}$ value of yogurt decreased at a higher percentage of puree-inoculated medium. Pineapple puree is rich in soluble carbohydrates, which support the growth of bacteria. LAB-synthesized lactic acid reduced the $\mathrm{pH}$ value of the yoghurt. The $\mathrm{pH}$ of the yoghurt declined based on the interactions between the nutrient composition of the pineapple puree and organic acid production. The decreased $\mathrm{pH}$ level under various storage conditions in relation 
to the starter culture and composition of fruit puree has been described previously [67]. Generally, addition of fruit pulp decreases the $\mathrm{pH}$ of yogurt, as reported previously [68].

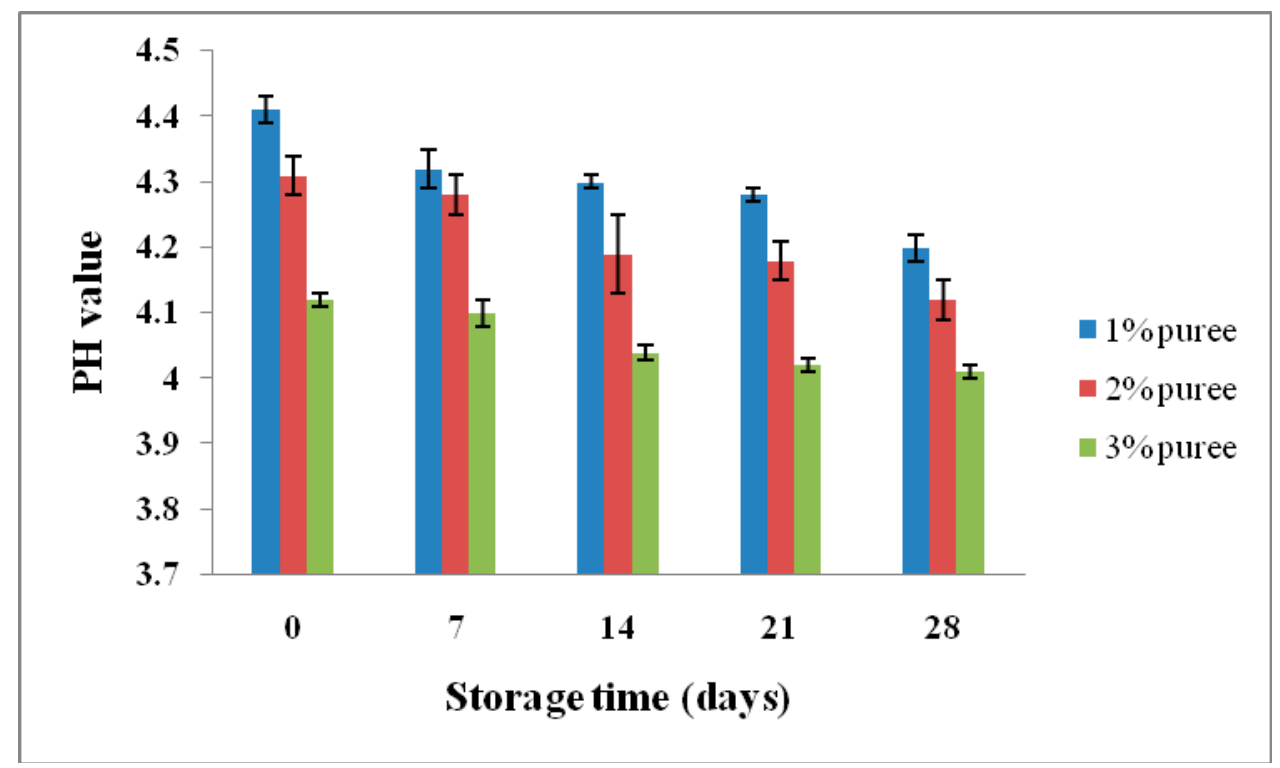

Figure 1. Influence of pineapple puree on goatmilk yogurt during storage.

\subsection{Bacterial Population and Sensory Characteristics of Yogurt during Storage}

Yogurt supplemented with $3 \%$ puree decreased the number of bacteria considerably compared with the $1 \%$ and $2 \%$ starter cultures. Supplementation of $1-3 \%$ puree reduced the total bacteria, and was mainly related to the antibacterial property of bromelain, an important component of pineapple. Yoghurt treated with $1 \%$ pineapple puree measured $15 \times 10^{2} \mathrm{CFU} / \mathrm{mL}$, and decreased to $10 \times 10^{-2} \mathrm{CFU} / \mathrm{mL}$ when the yogurt was prepared using $3 \%$ puree (Table 8 ). The decreasing bacterial population was mainly due to the antibacterial activity of bromelain. The antibacterial activity of bromelain has been described previously [69]. In the yogurt, fecal coliforms were not detected. The microbial populationof yogurt from South Africa, Argentina, Greece, Norway, France, Spain, Australia, and the United States was examined, and the bacteria such as L. delbrueckii subsp. Bulgaricus and $S$. thermophilus were determined in the range of $<10^{4}$ to $10^{9} \mathrm{CFU} / \mathrm{mL}$. The population of S. thermophilus was higher than L. delbrueckii subsp. bulgaricus. The level of Lactobacillus spp. was about $10^{8} \mathrm{CFU} / \mathrm{g}$ [70]. In this study, the addition of puree did not affect the properties of yogurt. The evaluated sensory characteristics, such as appearance, texture, and flavor showed a moderate decreasing tend in all three treated yogurts $(1 \%, 2 \%$, and $3 \%)$. However, no significant difference was observed among experimental groups. During the post-fermentation storage or fermentation process, adjunct cultures or probiotics could mostly cause various complex chemical and physical changes, such as acidification and hydrolysis, as well as the formation of amino acids and other compounds. Within 28 days of storage in a refrigerator, the sensory properties were desirable for consumption. Recently, a Bifidobacterium monoculture was used to prepare yogurt from goat milk, and desired sensory characteristics were detected up to 21 days of storage [71]. Natural sources are rich in polyphenols and have antimicrobial and antioxidant activities [72]. Recently, Cheon et al. [73] reported probiotic and neuroprotective properties of Lactobacillus buchneri KU200793 isolated from Korean fermented foods. The inoculation of probiotics in food products requires specific techniques, as probiotic bacteria can experience stress during food processing and gastrointestinal transit [74]. Survival of bacteria in harsh environments is a prerequisite for the selection of probiotic bacteria. Most probiotic organisms show poor resistance to various technological processes, and this leads to limitations in the use of various food products. Improving bacterial resistance by adaptation or microencapsulation may allow these bacterial strains to be used to formulate varieties of functional food. 
Table 8. Microbial population in yogurt during storage.

\begin{tabular}{cccc}
\hline \multirow{2}{*}{ Microorganisms } & \multicolumn{3}{c}{ Treatment } \\
\cline { 2 - 4 } & $\mathbf{1 \%}$ Puree & $\mathbf{2 \%}$ Puree & 3\% Puree \\
\hline Coliforms $(\mathrm{CFU} / \mathrm{mL})$ & $\mathrm{ND}$ & $\mathrm{ND}$ & $\mathrm{ND}$ \\
Total bacteria $\left(\times 10^{-8} \mathrm{CFU} / \mathrm{mL}\right)$ & 2.81 & 1.32 & 1.03 \\
Fungi $\left(\times 10^{-2} \mathrm{CFU} / \mathrm{mL}\right)$ & 15 & 13 & 10 \\
\hline
\end{tabular}

\section{Conclusions}

The present study investigates the effect of antioxidant and antimicrobial potential of Lactobacillus strains isolated from pineapple puree. Pineapple puree was used as the starter culture for the formation of yogurt from goat milk, and the properties of yogurt were investigated for 28 days of post-fermentation storage. Two Lactobacillus species, namely L. reuteri LR12 and L. lactis LL10, survived well in cold storage. The addition of pineapple puree up to 3\% did not cause any physical and sensory changes compared to the control. The flavor and other physical properties were similar in yogurt inoculated with $1-2 \%$ pineapple puree. The flavor of pineapple puree mediated yogurt fermentation, and this process may have significant application in the dairy industry.

Author Contributions: All authors contributed to this study. M.V.A., N.A.A.-D., G.A.E., V.D., Y.O.K., H.-J.K., H.K., and P.V. performed the experiment, analyzed the data, and edited the manuscript. Y.O.K., H.-J.K., H.K., and P.V. performed the antioxidant experiment and evaluated the draft. All authors have read and agree to the published version of the manuscript.

Funding: This work was supported by the Soonchunhyang University Research Fund. The authors would like to extend their sincere appreciation to the Deanship of Scientific Research at King Saud University for its funding of this research through the Research Group Project No. RG-1440-107.

Conflicts of Interest: The authors declare no conflict of interest.

\section{References}

1. Lewis, K. The science of antibiotic discovery. Cell 2020, 182, 29-45. [CrossRef]

2. Cepas, V.; López, Y.; Muñoz, E.; Rolo, D.; Ardanuy, C.; Martí, S.; Xercavins, M.; Horcajada, J.P.; Bosch, J.; Soto, S.M. Relationship between biofilm formation and antimicrobial resistance in gram-negative Bacteria. Microb. Drug Resist. 2019, 25, 72-79. [CrossRef] [PubMed]

3. Sosa-Moreno, A.; Comstock, S.S.; Sugino, K.Y.; Ma, T.F.; Paneth, N.; Davis, Y.; Olivero, R.; Schein, R.; Maurer, J.; Zhang, L. Perinatal risk factors for fecal antibiotic resistance gene patterns in pregnant women and their infants. PLoS ONE 2020, 15, e0234751. [CrossRef] [PubMed]

4. Patel, B.; Kumar, P.; Banerjee, R.; Basu, M.; Pal, A.; Samanta, M.; Das, S. Lactobacillus acidophilus attenuates Aeromonashydrophila induced cytotoxicity in catla thymus macrophages by modulating oxidative stress and inflammation. Mol. Immunol. 2016, 75, 69-83. [CrossRef] [PubMed]

5. Yang, C.S.; Lee, J.S.; Rodgers, M.; Min, C.K.; Lee, J.Y.; Kim, H.J.; Lee, K.H.; Kim, C.J.; Oh, B.; Zandi, E.; et al. Autophagy protein Rubicon mediates phagocytic NADPH oxidase activation in response to microbial infection or TLR stimulation. Cell Host Microbe 2012, 11, 264-276. [CrossRef]

6. Mu, G.; Gao, Y.; Tuo, Y.; Li, H.; Zhang, Y.; Qian, F.; Jiang, S. Assessing and comparing antioxidant activities of lactobacilli strains by using different chemical and cellular antioxidant methods. J. Dairy Sci. 2018, 101, 10792-10806. [CrossRef] [PubMed]

7. Mishra, V.; Shah, C.; Mokashe, N.; Chavan, R.; Yadav, H.; Prajapati, J. Probiotics as potential antioxidants: A systematic review. J. Agric. Food Chem. 2015, 63, 3615-3626. [CrossRef]

8. Dehkordi, S.S.; Alemzadeh, I.; Vaziri, A.S.; Vossoughi, A. Optimization of alginate-whey protein isolate microcapsules for survivability and release behavior of probiotic bacteria. Appl. Biochem. Biotechnol. 2020, 90, 182-196. [CrossRef]

9. Sivan, A.; Corrales, L.; Hubert, N.; Williams, J.B.; Aquino-Michaels, K.; Earley, Z.M.; Benyamin, F.W.; Lei, Y.M.; Jabri, B.; Alegre, M.L.; et al. Commensal Bifidobact-erium promotes antitumor immunity and facilitates anti-PD-L1 efficacy. Science 2015, 350, 1084-1089. [CrossRef] 
10. Giraffa, G.; Chanishvili, N.; Widyastuti, Y. Importance of lactobacilli in food and feed biotechnology. Res. Microbiol. 2010, 161, 480-487. [CrossRef]

11. Elyas, Y.Y.; Yousif, N.M.; Ahmed, I.A.M. Screening of lactic acid bacteria from Sudanese fermented foods for bacteriocin production. J. Microbiol. Biotechnol. Food Sci. 2020, 9, 373-378. [CrossRef]

12. Kechagia, M.; Basoulis, D.; Konstantopoulou, S.; Dimitriadi, D.; Gyftopoulou, K.; Skarmoutsou, N.; Fakiri, E.M. Health benefits of probiotics: A review. ISRN Nutr. 2013, 2013, 481651. [CrossRef] [PubMed]

13. Guo, X.H. Probiotic Lactic Acid Bacteria: Molecular Biology and Biotechnology; Science and Technology Press: Beijing, China, 2008.

14. Naito, Y.; Uchiyama, K.; Takagi, T. A next-generation beneficial microbe: Akkermansia muciniphila. J. Clin. Biochem. Nutr. 2018, 63, 33-35. [CrossRef] [PubMed]

15. Mbye, M.; Baig, M.A.; AbuQamar, S.F.; El-Tarabily, K.A.; Obaid, R.S.; Osaili, T.M.; Al-Nabulsi, A.A.; Turner, M.S.; Shah, N.P.; Ayyash, M.M. Updates on understanding of probiotic lactic acid bacteria responses to environmental stresses and highlights on proteomic analyses. Compr. Rev. Food Sci. Food Saf. 2020, 19, 1110-1124. [CrossRef]

16. Lim, S.M.; Lee, N.K.; Paik, H.D. Antibacterial and anticavity activity of probiotic Lactobacillus plantarum 200661 isolated from fermented foods against Streptococcus mutans. LWT 2020, 118, 108840. [CrossRef]

17. Hassan, M.; Kjos, M.; Nes, I.F.; Diep, D.B.; Lotfipour, F. Natural antimicrobial peptides from bacteria: Characteristics and potential applications to fight against antibiotic resistance. J. Appl. Microbiol. 2012, 113, 723-736. [CrossRef]

18. Nitisinprasert, S.; Pungsungworn, N.; Wanchaitanawong, P.; Loiseau, G.; Montet, D. In vitro adhesion assay of lactic acid bacteria, Escherichia coli and Salmonella sp. by microbiological and PCR methods. Songklanakarin J. Sci. Technol. 2006, 28 (Suppl. 1), 99-106.

19. Chen, C.C.; Lai, C.C.; Huang, H.L.; Huang, W.Y.; Toh, H.S.; Weng, T.C.; Chuang, Y.C.; Lu, Y.C.; Tang, H.J. Antimicrobial activity of Lactobacillus species against carbapenem-resistant Enterobacteriaceae. Front. Microbiol. 2019, 10, 789. [CrossRef]

20. Kaur, S.; Sharma, P.; Kalia, N.; Singh, J.; Kaur, S. Anti-biofilm Properties of the Fecal Probiotic Lactobacilli Against Vibrio spp. Front. Cell. Infect. Microbiol. 2018, 8, 120. [CrossRef]

21. Arasu, M.V.; Jung, M.W.; Ilavenil, S.; Jane, M.; Kim, D.H.; Lee, K.D.; Park, H.S.; Hur, T.Y.; Choi, G.J.; Lim, Y.C.; et al. Isolation and characterization of antifungal compound from Lactobacillus plantarum KCC-10 from forage silage with potential beneficial properties. J. Appl. Microbiol. 2013, 115, 1172-1185. [CrossRef]

22. McConnell, M.A.; Tannock, G.W. A note on lactobacilli and $\beta$-glucuronidase activity in the intestinal contents of mice. J. Appl. Bacteriol. 1993, 74, 649-651. [CrossRef] [PubMed]

23. Wu, C.C.; Lin, C.T.; Wu, C.Y.; Peng, W.S.; Lee, M.J.; Tsai, Y.C. Inhibitory effect of Lactobacillus salivarius on Streptococcus mutans biofilm formation. Mol. Oral Microbiol. 2015, 30, 16-26. [CrossRef] [PubMed]

24. Koo, H.; Rosalen, P.L.; Cury, J.A.; Park, Y.K.; Bowen, W.H. Effects of compounds found in propolis on Streptococcus mutans growth and on glucosyltransferase activity. Antimicrob. Agents Chemother. 2002, 46, 1302-1309. [CrossRef]

25. Wang, M.B.; Xu, H.; Xu, M.F.; Zeng, Z.; Wei, H. Efficacy of oral Bifidobacterium bifidum ATCC 29521 on microflora and antioxidant in mice. Can. J. Microbiol. 2016, 62, 249-262. [CrossRef] [PubMed]

26. Liu, W.; Wang, H.Y.; Pang, X.B.; Yao, W.B.; Gao, X.D. Characterization and antioxidant activity of two low-molecular-weight polysaccharides purified from the fruiting bodies of Ganoderma lucidum. Int. J. Biol. Macromol. 2010, 46, 451-457. [CrossRef] [PubMed]

27. Oyaizu, M. Studies on products of browning reaction: Antioxidative activities of products of browning reaction prepared from glucosamine. Jap. J. Nut. 1986, 44, 307-315. [CrossRef]

28. Lee, W.J.; Lucey, J.A. Formation and Physical Properties of Yoghurt. Asian-Aust. J. An. Sci. 2010, 23, 1127-1130. [CrossRef]

29. AOAC. Official Methods of Analysis, 15th ed.; AOAC: Arlington, VI, USA, 1990.

30. Favaro Trindade, C.S.; Terzi, S.C.; Trugo, L.C.; Della Modesta, R.C.; Couri, S. Development and sensory evaluation of soy milk based yoghurt. Arch. Latinoam. Nut. 2001, 51, 100-104.

31. Casado, C.; Benomar, N.; Lerma, L.L.; Gálvez, A.; Abriouel, H. Antibiotic resistance of Lactobacillus pentosus and Leuconostoc pseudomesenteroides isolated from naturally-fermented Aloreña table olives throughout fermentation process. Int. J. Food Microbiol. 2014, 172, 110-118. [CrossRef] [PubMed] 
32. Martino, G.P.; Espariz, M.; Nizo, G.G.; Esteban, L.; Blancato, V.S.; Magni, C. Safety assessment and functional properties of four enterococci strains isolated from regional Argentinean cheese. Int. J. Food Microbiol. 2018, 277, 1-9. [CrossRef]

33. Zielińska, D.; Kolożyn-Krajewska, D. Food-origin lactic acid bacteria may exhibit probiotic properties. Biomed. Res. Int. 2018, 2018, 5063185. [CrossRef]

34. Han, Q.; Kong, B.; Chen, Q.; Sun, F.; Zhang, H. In Vitro comparison of probiotic properties of lactic acid bacteria isolated from Harbin dry sausages and selected probiotics. J. Fun. Food 2017, 32, 391-400. [CrossRef]

35. Jones, B.V.; Begley, M.; Hill, C.; Gahan, C.G.; Marchesi, J.R. Functional and comparative metagenomic analysis of bile salt hydrolase activity in the human gut microbiome. Proc. Natl. Acad. Sci. USA 2008, 105, 13580-13585. [CrossRef] [PubMed]

36. Dong, Z.; Zhang, J.; Lee, B.; Li, H.; Du, G.; Chen, J. A bile salt hydrolase gene of Lactobacillus plantarum BBE7 with high cholesterol-removing activity. Eur. Food Res. Technol. 2012, 235, 419-427. [CrossRef]

37. Gill, C.I.R.; Rowland, I.R. Diet and cancer: Assessing the risk. Br. J. Nutr. 2002, 88, S73-S87. [CrossRef]

38. Kim, D.H.; Jin, Y.H. Intestinal bacterial b-glucuronidase activity of patients with colon cancer. Arch. Pharm. Res. 2001, 24, 564-567. [CrossRef]

39. Kos, B.; Šušković, J.; Vuković, S.; Šimpraga, M.; Frece, J.; Matošić, S. Adhesion and aggregation ability of probiotic strain Lactobacillus acidophilus M92. J. Appl. Microbiol. 2003, 94, 981-987. [CrossRef]

40. Von Ossowski, I.; Reunanen, J.; Satokari, R.; Vesterlund, S.; Kankainen, M.; Huhtinen, H.; Tynkkynen, S.; Salminen, S.; de Vos, W.M.; Palva, A. Mucosal adhesion properties of the probiotic Lactobacillus rhamnosus GG SpaCBA and SpaFED pilin subunits. Appl. Environ. Microbiol. 2010, 76, 2049-2057. [CrossRef]

41. Kirtzalidou, E.; Pramateftaki, P.; Kotsou, M.; Kyriacou, A. Screening for lactobacilli with probiotic properties in the infant gut microbiota. Anaerobe 2011, 17, 440-443. [CrossRef]

42. Tuo, Y.; Yu, H.; Ai, L.; Wu, Z.; Guo, B.; Chen, W. Aggregation and adhesion properties of 22 Lactobacillus strains. J. Dairy Sci. 2013, 96, 4252-4257. [CrossRef]

43. Servin, A.L. Antagonistic activities of lactobacilli and bifidobacteria against microbial pathogens. FEMS Microbiol. Rev. 2004, 28, 405-440. [CrossRef] [PubMed]

44. Zacharof, M.P.; Lovitt, R.W. Bacteriocins produced by lactic acid bacteria a review article. APCBEE Procedia 2012, 2, 50-56. [CrossRef]

45. Jamalifar, H.; Rahimi, H.; Samadi, N.; Shahverdi, A.; Sharifian, Z.; Hosseini, F.; Eslahi, H.; Fazeli, M.R. Antimicrobial activity of different Lactobacillus species against multi-drug resistant clinical isolates of Pseudomonas aeruginosa. Iran. J. Microbiol. 2011, 3, 21-25. [PubMed]

46. Mirnejad, R.; Vahdati, A.R.; Rashidiani, J.; Erfani, M.; Piranfar, V. The antimicrobial effect of Lactobacillus casei culture supernatant against multiple drug resistant clinical isolates of Shigella sonnei and Shigella flexneri in vitro. Iran. Red Crescent Med. J. 2013, 15, 122-126. [CrossRef]

47. Kumar, M.; Dhaka, P.; Vijay, D.; Vergis, J.; Mohan, V.; Kumar, A.; Kurkure, N.V.; Barbuddhe, S.B.; Malik, S.V.S.; Rawool, D.B. Antimicrobial effects of Lactobacillus plantarum and Lactobacillus acidophilus against multidrug-resistant enteroaggregative Escherichia coli. Int. J. Antimicrob. Agents 2016, 48, 265-270. [CrossRef] [PubMed]

48. Kang, M.S.; Lim, H.S.; Oh, J.S.; Lim, Y.J.; Wuertz-Kozak, K.; Harro, J.M. Antimicrobial activity of Lactobacillus salivarius and Lactobacillus fermentum against Staphylococcus aureus. Pathog. Dis. 2017, 75, ftx009. [CrossRef]

49. Ahn, K.B.; Baik, J.E.; Park, O.J.; Yun, C.H.; Han, S.H. Lactobacillus plantarum lipoteichoic acid inhibits biofilm formation of Streptococcus mutans. PLoS ONE 2018, 13, e0192694. [CrossRef]

50. Wang, L.; Zhang, H.; Rehman, M.U.; Mehmood, K.; Jiang, X.; Iqbal, M.; Tong, X.; Gao, X.; Li, J. Antibacterial activity of Lactobacillus plantarum isolated from Tibetan yaks. Microb. Pathogen. 2018, 115, 293-298. [CrossRef]

51. Zhang, Y.; Zhang, L.; Du, M.; Yi, H.; Guo, C.; Tuo, Y.; Shirtliff, M.E.; Achermann, Y. Antimicrobial activity against Shigella sonnei and probiotic properties of wild lactobacilli from fermented food. Microbiol. Res. 2011, 167, 27-31. [CrossRef]

52. Farida, F.; Nassim, M.; Djamila, S. Beneficial effects of a strain of Lactobacillus paracasei subsp. paracasei in Staphylococcus aureus-induced intestinal and 318 colonic injury. Int. J. Infect. Dis. 2011, 15, 787-794.

53. Melo, T.A.; Dos Santos, T.F.; de Almeida, M.E.; Junior, L.A.G.F.; Andrade, E.F.; Rezende, R.P.; Marques, L.M.; Romano, C.C. Inhibition of Staphylococcus aureus biofilm by Lactobacillus isolated from fine cocoa. BMC Microbiol. 2016, 16, 1-9. [CrossRef]

54. Tahmourespour, A.; Salehi, R.; Kermanshahi, R.K.; Eslami, G. The anti-biofouling effect of Lactobacillus fermentum-derived biosurfactant against Streptococcus mutans. Biofouling 2011, 27, 385-392. [CrossRef] [PubMed] 
55. Rivardo, F.; Turner, R.J.; Allegrone, G.; Ceri, H.; Martinotti, M.G. Anti-adhesion activity of two biosurfactants produced by Bacillus spp. prevents biofilm formation of human bacterial pathogens. Appl. Microbiol. Biotechnol. 2009, 83, 541-553. [CrossRef]

56. Anunthawan, T.; de la Fuente-Nunez, C.; Hancock, R.E.; Klaynongsruang, S. Cationic amphipathic peptides KT2 and RT2 are taken up into bacterial cells and kill planktonic and biofilm bacteria. Biochim. Biophys. Acta 2015, 1848, 1352-1358. [CrossRef]

57. Thibessard, A.; Borges, F.; Fernandez, A.; Gintz, B.; Decaris, B.; Leblond-Bourget, N. Identification of Streptococcus thermophilus CNRZ368 genes involved in defense against superoxide stress. Appl. Environ. Microbiol. 2004, 70, 2220-2229. [CrossRef]

58. Almalki, M.A. Exopolysaccharide production by a new Lactobacillus lactis isolated from the fermented milk and its antioxidant properties. J. King Saud. Uni. Sci. 2020, 32, 1272-1277. [CrossRef]

59. Liu, C.F.; Pam, T.M. In Vitro effects of lactic acid bacteria on cancer cell viability and antioxidant activity. J. Food Drug Anal. 2010, 18, 77-86. [CrossRef]

60. Kullisaar, T.; Zilmer, M.; Mikelsaar, M.; Vihalemm, T.; Annuk, H.; Kairane, C.; Kilk, A. Two antioxidative lactobacilli strains as promising probiotics. Int. J. Food Microbiol. 2002, 72, 215-224. [CrossRef]

61. Lin, M.Y.; Yen, C.L. Antioxidative ability of lactic acid bacteria. J. Agric. Food Chem. 1999, 47, 1460-1466. [CrossRef] [PubMed]

62. Wojcik, M.; Burzynska-Pedziwiatr, I.; Wozniak, L.A. A review of natural and synthetic antioxidants important for health and longevity. Curr. Med. Chem. 2010, 17, 3262-3288. [CrossRef]

63. Arasu, M.V.; Kim, D.H.; Kim, P.I.; Jung, M.W.; Ilavenil, S.; Jane, M.; Lee, K.D.; Al-Dhabi, N.A.; Choi, K.C. In vitro antifungal, probiotic and antioxidant properties of novel Lactobacillus plantarum $\mathrm{K} 46$ isolated from fermented sesame leaf. Ann. Microbiol. 2014, 64, 1333-1346. [CrossRef]

64. Nikoofar, E.; Hojjatoleslami, M.; Shariaty, M.A. Surveying the effect of quince seed mucilage as a fat replacer on texture and physicochemical properties of semi fat set yoghurt. Int. J. Farm Alli. Sci. 2013, 2, 861-865.

65. Ramchandran, L.; Shah, N.P. Characterization of functional, biochemical and textural properties of symbiotic low-fat yoghurts during refrigerated storage. LWT_Food Sci. Technol. 2010, 43, 819-827. [CrossRef]

66. Walter, T. New application specific fat replacers for the dairy industry. Int. Food Ingre. 1993, 4, $29-32$.

67. Yeganehzad, S.; Mazaheri-Tehrani, M.; Shahidi, F. Studying microbial, physiochemical and sensory properties of directly concentrated probiotic yoghurt. Afr. J. Agric. Res. 2007, 2, 366-369.

68. Frazier, W.C.; Westhhoff, D.C. Food Microbiology; Mc Graw-Hill Book Company: New York, NY, USA, 1995.

69. Dos Anjos, M.M.; da Silva, A.A.; de Pascoli, I.C.; Mikcha, J.M.G.; Machinski, M., Jr.; Peralta, R.M.; de Abreu Filho, B.A. Antibacterial activity of papain and bromelain on Alicyclobacillus spp. Int. J. Food Microbiol. 2016, 216, 121-126. [CrossRef]

70. Rezac, S.; Kok, C.R.; Heermann, M.; Hutkins, R. Fermented Foods as a Dietary Source of Live Organisms. Front. Microbiol. 2018, 9, 1785. [CrossRef]

71. Mituniewicz-Małek, A.; Ziarno, M.; Dmytrów, I.; Balejko, J. Effect of the addition of Bifidobacterium monocultures on the physical, chemical, and sensory characteristics of fermented goat milk. J. Dairy Sci. 2017, 100, 6972-6979. [CrossRef]

72. Vamanu, E.; Gatea, F.; Pelinescu, D.R. Bioavailability and Bioactivities of Polyphenols Eco Extracts from Coffee Grounds after In Vitro Digestion. Foods 2020, 9, 1281. [CrossRef]

73. Cheon, M.J.; Lim, S.M.; Lee, N.K.; Paik, H.D. Probiotic Properties and Neuroprotective Effects of Lactobacillus buchneri KU200793 Isolated from Korean Fermented Foods. Int. J. Mol. Sci. 2020, 21, 1227. [CrossRef]

74. Speranza, B.; Campaniello, D.; Petruzzi, L.; Altieri, C.; Sinigaglia, M.; Bevilacqua, A.; Rosaria Corbo, M. The Inoculation of Probiotics In Vivo Is a Challenge: Strategies to Improve Their Survival, to Avoid Unpleasant Changes, or to Enhance Their Performances in Beverages. Beverages 2020, 6, 20. [CrossRef]

(C) 2020 by the authors. Licensee MDPI, Basel, Switzerland. This article is an open access article distributed under the terms and conditions of the Creative Commons Attribution (CC BY) license (http://creativecommons.org/licenses/by/4.0/). 